Full-length article

\title{
Tanshinone IIA inhibits endothelin-1 production in TNF- $\alpha$-induced brain microvascular endothelial cells through suppression of endothelin-con- verting enzyme-1 synthesis
}

\author{
Chao TANG ${ }^{1}$, An-hua WU ${ }^{1,3}$, Hong-li XUE ${ }^{2}$, Yun-jie WANG ${ }^{1}$ \\ ${ }^{1}$ Department of Neurosurgery, the First Affiliated Hospital, China Medical University; ${ }^{2}$ Department of Neurosurgery, General Hospital of \\ Shenyang Military Command, Shenyang 110001,China.
}

\section{Key words}

tanshinone IIA; endothelin-1; TNF- $\alpha$; brain microvascular endothelial cells

\author{
${ }^{3}$ Correspondence to Prof An-hua WU. \\ Phn 86-24-8328-3385. \\ Fax 86-24-8328-3390. \\ E-mailanhuawu001@yahoo.com.cn
}

Received 2006-11-03

Accepted 2007-02-13

doi: $10.1111 / \mathrm{j} .1745-7254.2007 .00598 . \mathrm{x}$

\begin{abstract}
Aim: To investigate the effects of tanshinone IIA (Tan IIA) on the regulation of the production of endothelin (ET)-1 (including large ET-1), mRNA levels of ET-1, endothelin-converting enzyme-1 (ECE-1), endothelin-A receptor $\left(\mathrm{ET}_{\mathrm{A}}\right)$ and endothelin-B receptor $\left(\mathrm{ET}_{\mathrm{B}}\right)$ induced by $\mathrm{TNF}-\alpha$ in rat brain microvascular endothelial cells (BMVEC). Methods: The ET-1 release (including large ET-1) into the culture medium was determined by enzyme immunoassay. The levels of ET-1, $\mathrm{ECE}-1, \mathrm{ET}_{\mathrm{A}}$, and $\mathrm{ET}_{\mathrm{B}} \mathrm{mRNA}$ were measured byRT-PCR. Endothelin receptor binding was also tested. Results: The induction of ET-1 release by TNF- $\alpha$ from cultured BMVEC was dose-dependently reduced by Tan IIA, but large ET-1 levels progressively increased in response to Tan IIA; the mRNA expression of ET-1 was unaffected. Tan IIA also caused a decrease in $\mathrm{ET}_{\mathrm{A}}$ receptor mRNA and ECE-1 expression in a dose-dependent manner. Endothelin receptor binding was unaltered in BMVEC stimulated with TNF- $\alpha$ alone or a combination of TNF- $\alpha$ and Tan IIA. Conclusion: These findings suggest that Tan IIA may inhibit ET-1 production in TNF- $\alpha$-induced BMVEC through the suppression of ECE-1 synthesis.
\end{abstract}

\section{Introduction}

Endothelin (ET)-1 is a 21-amino-acid peptide isolated from endothelial cells. It has been found to be one of the most potent vasoconstrictor peptides in humans and is involved in the regulation of cerebral blood flow ${ }^{[1]}$. In addition, ET-1 has been implicated as a mediator of cerebrovascular responses in ischemic stroke and subarachnoid hemorrhage $(\mathrm{SAH})^{[2,3]}$. ET-1 binds with high affinity to the endothelin-A receptor $\left(\mathrm{ET}_{\mathrm{A}}\right)$, which mediates vasoconstriction by activating the phospholipase $\mathrm{C}$ /protein kinase $\mathrm{C}$ cascade, decreasing smooth muscle sensitivity to nitric oxide (NO), and increasing cytosolic free calcium levels and superoxide anion production ${ }^{[4]}$. The endothelin-B receptor $\left(\mathrm{ET}_{\mathrm{B}}\right)$ has a lower affinity for ET-1 and mediates vascular relaxation, although some vasoconstrictor activity of $\mathrm{ET}_{\mathrm{B}}$ has also been shown ${ }^{[5]}$. Large ET is a precursor to endothelin with almost no vasoconstrictor activity. ET-1 is formed when large ET-1 is cleaved by endothelin-converting enzyme-1 (ECE-1). ECE-1 has been extensively detected in the human brain ${ }^{[6]}$, and increased serum ECE-1 activity reflects the severity of endothelial injury to cerebral arteries ${ }^{[7]}$. The use of ECE-1 inhibitors can prevent and reverse cerebral vasospasm following SAH. ECE-1 inhibitors are expected to be efficacious in the treatment of various cerebrovascular disease ${ }^{[8]}$.

TNF- $\alpha$ contributes to the pathology of a broad spectrum of central nervous system diseases and injury via its action on endothelial function. It has been shown that ET-1 can be modulated by TNF- $\alpha$. ET-1 and ECE-1 mRNA are upregulated in response to TNF- $\alpha$ in endothelial cells ${ }^{[9-11]}$. To further our understanding on how tanshinone IIA (Tan IIA) could mediate the ET system, we examined the effect of TNF- $\alpha$ on $\mathrm{ET}_{\mathrm{A}}$ and $\mathrm{ET}_{\mathrm{B}}$ mRNA, and alterations of ET-1 binding to its receptors in the present study.

The rhizome of Salvia miltiorrhiza Bunge (SM), also known as Tanshen, is an important herb for promoting the 
circulation of blood and eliminating stasis in Chinese traditional medicine. Previous reports have shown that SM can prevent the postoperative increase of ET-1 after cardiopulmonary bypass in children with congenital heart defects. It can also inhibit ET-1 production and stimulate NO production in human vascular endothelial and mesangial cells ${ }^{[12-15]}$. However, the mechanisms underlying the therapeutic action of SM are not well understood. Tan IIA is one of the major diterpenes from SM. It can reduce brain infarct volume in transient focal cerebral ischemia, and can markedly inhibit the production of NO, interleukin-1 $\beta$, and TNF- $\alpha$, and can suppress the expression of an inducible form of NO synthase in activated mouse leukaemic monocyte macrophage cell line ${ }^{[16]}$. However, the relationship between ET-1 and Tan IIA has not been well established. As a major lipid and soluble pharmacological constituent of SM, Tan IIA may be involved in the interaction between SM and ET-1 in cerebrovascular diseases. Thus, in the present study, we examined and compared the biochemical and molecular responses of the ET system in cultured rat brain microvascular endothelial cells (BMVEC) to TNF- $\alpha$ and Tan IIA in an attempt to elucidate the possible cerebrovascular effects of Tan IIA.

\section{Materials and methods}

Drugs and reagents RPMI-1640 medium and fetal bovine serum (FBS) were purchased from Gibco (Grand Island, NY, USA). TNF- $\alpha$, 3-(4,5-dimethylthiazol-2-yl)-2,5-diphenyl tetrazolium bromide (MTT), penicillin, streptomycin, dimethylsulphoxide $\left(\mathrm{Me}_{2} \mathrm{SO}\right)$, the ET-1 immunoassay kit, and ${ }^{125}$ I-ET-1 were obtained from Sigma (St Louis, MO, USA). All materials used were of analytical grade.

Preparation of Tan IIA extract Tan IIA was isolated from the roots of SM, based on the method described previously ${ }^{[17]}$. Briefly, SM was extracted with methanol at room temperature, and then partitioned by methylene chloride, ethyl acetate, and $n$-butanol in turn. The methylene chloride fraction was subjected to column chromatography over a silica gel eluting with a gradient system of hexane, ethyl acetate. The fractions were combined based on their thin-layer chromatography pattern to yield a sub-fraction designated as D1-D11. Sub-fraction D2 was further purified by repeated column chromatography over a silica gel to afford Tan IIA. The purity of Tan IIA used was more than $99 \%$, which was proven by HPLC according to the method for the assay of Tan IIA in Chinese Pharmacopoeia.

Isolation and culture of rat BMVEC Primaryrat BMVEC were isolated as previously described ${ }^{[18]}$. Briefly, fresh rat brains were obtained from 6-week-old Wister rats, placed into ice-cold buffer A (10 mmol/L hydroxyethyl piperazine ethanesulfonic acid, $11.9 \mathrm{mmol} / \mathrm{LNaHCO}_{3}, 140 \mathrm{mmol} / \mathrm{LNaCl}, 10$ $\mathrm{mmol} / \mathrm{L} \mathrm{KCl}$, and $0.1 \%$ bovine serum albumin). The cortices were cut into $2-3 \mathrm{~mm}$ pieces, further digested in a $0.1 \%$ collagenase/dispase solution to separate the microvessels from other components, and then centrifuged. The pellet containing crude microvessels was further digested in a second collagenase/dispase solution for $2 \mathrm{~h}$. Microvascular endothelial cells were purified by a Percoll gradient.

The cells were maintained in an atmosphere of $5 \% \mathrm{CO}_{2}$ at $37^{\circ} \mathrm{C}$ in RPMI-1640 medium supplemented with 10\% FBS, $100 \mathrm{U} / \mathrm{mL}$ penicillin, and $100 \mathrm{mg} / \mathrm{mL}$ streptomycin. The cells of passages 3 and 4 were used for the experiments at $>80 \%$ confluency. The BMVEC were verified by staining with factor VIII, Von Willebrand factor. The cells were stimulated with TNF- $\alpha(5 \mu \mathrm{g} / \mathrm{mL})$ in the presence or absence of Tan IIA at the indicated concentrations. The stock solutions of Tan IIA were dissolved in $\mathrm{Me}_{2} \mathrm{SO}$. The concentration of $\mathrm{Me}_{2} \mathrm{SO}$ in the final culture media was $0.1 \%(v / v)$.

Evaluation of cell viability The cytotoxicity of Tan IIA was evaluated via the reduced activity of MTT. The cells were incubated for $24 \mathrm{~h}$ with Tan IIA at the indicated concentrations, and some cells were activated for $8 \mathrm{~h}$ with TNF- $\alpha(5 \mu \mathrm{g} / \mathrm{mL})$ after the pre-incubation of Tan IIA for $24 \mathrm{~h}$. MTT $(50 \mu \mathrm{g} / \mathrm{mL})$ was then added to each well. The formazan formed was dissolved in $\mathrm{Me}_{2} \mathrm{SO}$; optical density was measured using an ELISA microplate reader at $570 \mathrm{~nm}$ to represent cellular viability. The optical density of formazan formed in the control cells (medium alone) was taken as $100 \%$ viability.

Extraction and assay of ET-1, including large ET-1 Media samples were collected in ice-cold polypropylene tubes containing a solution of EDTA $(1 \mathrm{mg} / \mathrm{mL})$, and aprotinin $(500 \mathrm{kIU} / \mathrm{mL})$. The samples were extracted by addition of $1.0 \mathrm{~mL}$ trifluoroacetic acid (1\%) in $99 \%$ distilled water and centrifuged at $6000 \times \mathrm{g}$ for $20 \mathrm{~min}$ at $4{ }^{\circ} \mathrm{C}$. The supernatant was loaded onto a C-18 Sep column (Waters, Milford, MA, USA) that was previously equilibrated by washing with $100 \%$ acetonitrile followed by $1 \%$ TFA. The peptides were eluted slowly with $60 \%$ acetonitrile, $1 \%$ TFA, and 39\% distilled water. The eluent was collected in a clean polypropylene tube, evaporated to dryness, and reconstituted in assay buffer. ET-1 levels, including large ET-1, were determined using enzyme immunoassay kits. Each kit consisted of a polystyrene 96-well immunoplate pre-coated with a peptide antibody. Aliquots of the reconstituted samples were loaded in duplicate onto the wells, and the assay was carried out according to the manufacturer's protocol. Absorbance was measured at $450 \mathrm{~nm}$ in an automated plate reader. The absorbance was correlated with ET-1 concentrations, includ- 
ing large ET-1, to generate a standard curve that ranged from 0 to $1000 \mathrm{ng} / \mathrm{mL}$. The assay of ET-1, including large ET-1, was carried out in triplicate.

Quantitation of mRNA expression by RT-PCR Whole cell RNA was isolated by guanidine thiocyanate and cesium chloride gradient centrifugation. Total RNA ( $5 \mu \mathrm{g}$, determined spectrophotometrically) was used to generate firststrand cDNA by random priming with reagents and protocols used as recommended by the manufacturers (Pharmacia, Freiburg, Germany; Gibco, USA). The cDNA representing 50 ng input RNA was amplified by PCR using Taq polymerase (Gibco, USA ) in a reaction volume of $50 \mu \mathrm{L}$. Specific primer pairs, constructed from the reported rat gene sequence for ET-1, ECE-1, $\mathrm{ET}_{\mathrm{A}}$, and $\mathrm{ET}_{\mathrm{B}}$ (shown in Table 1, according to previous reports ${ }^{[19-21]}$ ) were applied as described previously. Both primer pairs were added simultaneously to the PCR reaction vials. Each primer pair amplified a single band of the expected size in a total volume of $50 \mu \mathrm{L}$ for each reaction. The following PCR profile was used: cDNA was denatured initially for $3 \mathrm{~min}$ at $94^{\circ} \mathrm{C}$ and then cycling started with denaturing at $94{ }^{\circ} \mathrm{C}$ for $45 \mathrm{~s}$, annealing at $54{ }^{\circ} \mathrm{C}$ for $30 \mathrm{~s}$, and extension at $72{ }^{\circ} \mathrm{C}$ for $90 \mathrm{~s}$. The last cycle included a prolonged extension at $72^{\circ} \mathrm{C}$ for $7 \mathrm{~min}$. For these experiments, an optimal PCR cycling length was used for each of the primer pairs, such that the PCR product-RNA relationship was kept in the log-linear phase. The number of cycles chosen was 30 for the $\mathrm{ET}_{\mathrm{A}}$ and $\mathrm{ET}_{\mathrm{B}}$ receptors and $\mathrm{ET}-1$, and 23 for ECE-1. All RT-PCR experiments were routinely controlled by conducting PCR omitting the reverse transcription. The samples were analyzed by agarose gel electrophoresis, with the agarose gel containing $0.4 \mu \mathrm{g} / \mathrm{mL}$ ethidium bromide and $0.5 \times$ Tris-acetateEDTA buffer. The bands were visualized with $302 \mathrm{~nm}$ light and photographed using a video processor (Mitsubishi, Tokyo, Japan). Quantitative data were obtained from a densi-

Table 1. Primers used for quantitative RT-PCR.

\begin{tabular}{lll}
\hline Rat & \multicolumn{1}{c}{ Primer } & \multicolumn{1}{c}{ Nucleotide sequence } \\
\hline & & \\
ET-1 & Sense & 5'-GCTCCTGCTCCTCCTTGATG-3' \\
ET-1 & Antisense & 5'-CTCGCTCTATGTAAGTCATGG-3' \\
ET $_{\mathrm{A}}$ & Sense & 5'-GTGTTTAAGCTGTTGGCGGG-3' \\
ET $_{\mathrm{A}}$ & Antisense & 5'-CGAGGTCATGAGGCTTTTGG-3' \\
ET $_{\mathrm{B}}$ & Sense & 5'-AGCTGGGTGCCCTTCATACAGAAGGC-3' \\
ET $_{\mathrm{B}}$ & Antisense & 5'-TGCACACCTTTCCGCAAGCACG-3' \\
ECE-1 Sense & 5'-CGTAGGGATAGTCTTAGCAC-3' \\
ECE-1 Antisense & 5'-GTGCCACACACAAAACTACAG-3' \\
$\beta$-actin & Sense & 5'-ATTGAGTATGAGTACAAGCTG-3' \\
$\beta$-actin & Antisense & 5'-CGCATCTCTCTCTCTTTGTC-3' \\
& & \\
\hline
\end{tabular}

tometer and analyzed with Quantity One 4.4.0 software (BioRad, Hercules, CA, USA). Each PCR assay was run in triplicate.

Radioligand binding studies Radiolabeled ET-1 binding was studied in living cells. The binding medium used was minimum essential medium with $50 \mathrm{mmol} / \mathrm{LHEPES}$ (pH 7.4), $0.1 \mathrm{mg} / \mathrm{mL}$ bacitracin, $0.1 \mu \mathrm{g} / \mathrm{mL}$ aprotinin, $0.48 \mu \mathrm{g} / \mathrm{mL}$ leupeptin, $0.68 \mu \mathrm{g} / \mathrm{mL}$ pepstatin A, $0.2 \mathrm{mmol} / \mathrm{L}$ phenylmethylsulfonyl fluoride, and $2.5 \mathrm{~g} / \mathrm{L}$ BSA. The cells were washed 3 times with $1.0 \mathrm{~mL}$ binding buffer. ${ }^{125} \mathrm{I}-\mathrm{ET}-11 \times 10^{-11}$ $\mathrm{mol} / \mathrm{L}$ and increasing concentrations of unlabeled ET- 1 in the presence or absence of TNF- $\alpha$ and Tan IIA at the indicated concentrations were added to each well. Incubations were done at $22{ }^{\circ} \mathrm{C}$ and terminated by aspiration of the binding medium and quick washing of the cells 3 times with $2.0 \mathrm{~mL}$ ice-cold binding medium. Counts were corrected for nonspecific binding or uptake by subtraction of the radioactivity measured in the presence of excess unlabeled ligand. Cell-bound radioactivity was counted with a Wallac 1470 gamma counter (Wallac Inc, Gaithersburg, MD, USA).

Statistical analysis Data were expressed as mean \pm SD. The statistical differences among the groups were evaluated using one-way ANOVA with Fisher's protected least significant difference test. $P<0.05$ was considered significant. Results were analyzed using SPSS 13.0 software (Spss Inc, Chicago, TL, USA).

\section{Results}

Effects of Tan IIA on cell viability The effect of Tan IIA on cell viability were investigated by MTT; the cells were exposed to Tan IIA for $24 \mathrm{~h}$. As shown in Figure 1, the

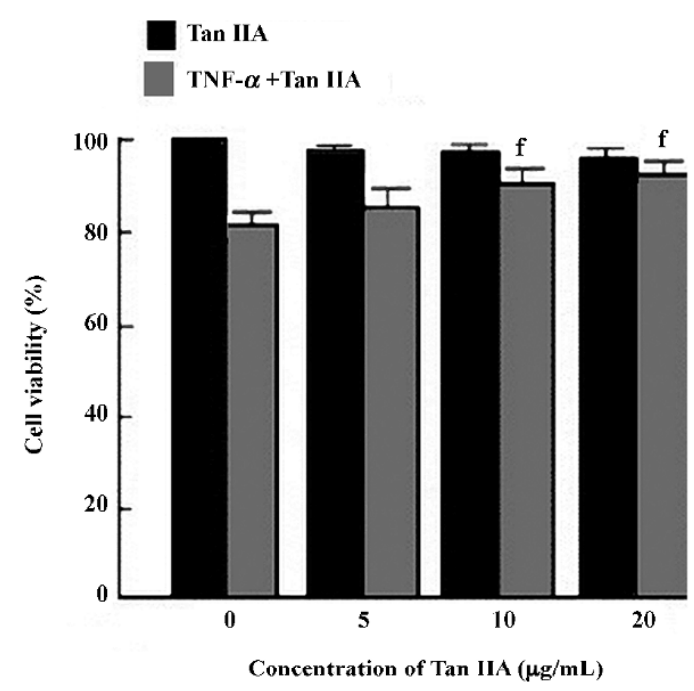

Figure 1. Effects of Tan IIA on cell viability. $n=6$. Mean \pm SD. ${ }^{\mathrm{b}} P<$ 0.05 vs TNF- $\alpha$ alone. 
concentrations $(0-20 \mu \mathrm{g} / \mathrm{mL})$ of Tan IIA used here had no effect on the viability of BMVEC. TNF- $\alpha$ at $5 \mu \mathrm{g} / \mathrm{mL}$ reduced the viability of BMVEC with cell viability at $82 \% \pm 3 \%$, but Tan IIA significantly reversed the TNF- $\alpha$-induced reduction of cell viability at concentrations of 10 and $20 \mu \mathrm{g} / \mathrm{mL}(90 \% \pm 3 \%$ and $93 \% \pm 3 \%$, respectively; $P<0.05$ vs $82 \% \pm 3 \% ; n=6)$. Tan IIA $(5 \mu \mathrm{g} / \mathrm{mL})$ increased cell viability, but the difference was not significant $(85 \% \pm 4 \% ; P>0.05$ vs $82 \% \pm 3 \% ; n=6)$.

Effects of Tan IIA on TNF- $\alpha$-induced ET-1 production, including large ET-1, in BMVEC As shown in Table 2, TNF- $\alpha$ significantly increased the ET-1 concentration in the media when the BMVEC were treated with Tan IIA. TNF- $\alpha-$ induced ET-1 elevation was suppressed in a dose-dependent manner. Quite a different response pattern became apparent for large ET-1 production. Large ET-1 levels decreased in response to TNF- $\alpha$. Conversely, large ET- 1 levels progressively increased in response to Tan IIA in a dosedependent manner.

Effects of Tan IIA on TNF- $\alpha$-induced ECE-1 activation in BMVEC As shown in Figure 2, the ECE-1 mRNA expression

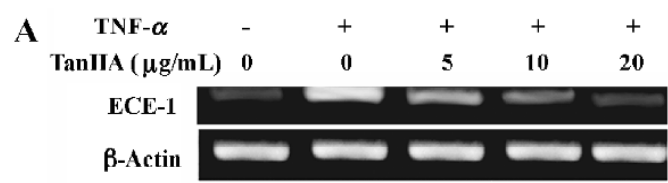

$\mathbf{B}$

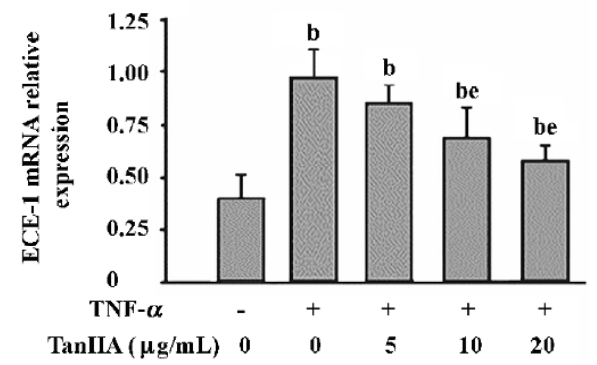

Figure 2. Effects of Tan IIA on TNF- $\alpha$-induced ECE-1 activation in BMVEC. $n=6$. Mean \pm SD. ${ }^{\mathrm{b}} P<0.05$ vs controls. ${ }^{\mathrm{e}} P<0.05$ vs TNF- $\alpha$ alone. (A) Detection of mRNA for ECE-1 and $\beta$-actin in the BMVEC. (B) Relative expression of ECE-1 normalized against $\beta$-actin. was determined by RT-PCR. The ECE-1 mRNA expression was significantly upregulated by TNF- $\alpha(0.97 \pm 0.13 ; P<0.05$ vs $0.39 \pm 0.10 ; n=6)$. TNF- $\alpha$-induced ECE- 1 activation was suppressed significantly by Tan IIA at concentrations of 10 and $20 \mu \mathrm{g} / \mathrm{mL}(0.69 \pm 0.14$ and $0.58 \pm 0.06$, respectively; $P<0.05$ vs $0.97 \pm 0.13 ; n=6)$. Tan IIA $(5 \mu \mathrm{g} / \mathrm{mL})$ downregulated ECE-1 mRNA, but the difference was not significant $(0.84 \pm 0.09$; $P>0.05$ vs $0.97 \pm 0.13, n=6$ ).

Effects of Tan IIA on TNF- $\alpha$-induced mRNA expression of ET-1 in BMVEC In order to investigate whether the decrease in ET-1 in the media might be related to an decrease in the ET-1 mRNA expression in BMVEC stimulated with TNF$\alpha$, RT-PCR analysis was performed. As shown in Figure 3, the expression of ET-1 significantly increased with TNF- $\alpha$ exposure ( $1.13 \pm 0.13 ; P<0.05$ vs $0.50 \pm 0.13 ; n=6)$. However, no alteration in ET-1 mRNA could be detected after incubation of the cells with Tan IIA at the indicated concentrations (5, 10 , and $20 \mu \mathrm{g} / \mathrm{mL}$ ) for $24 \mathrm{~h}$ prior to TNF- $\alpha$ compared with BMVEC stimulated with TNF- $\alpha$ alone $(1.08 \pm 0.09,1.10 \pm 0.12$,

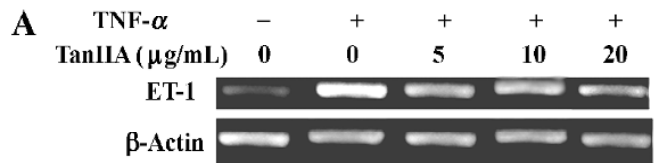

B

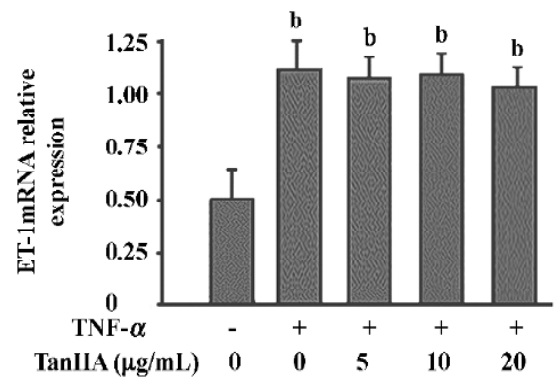

Figure 3. Effects of Tan IIA on the TNF- $\alpha$-induced mRNA expression of the ET- 1 in the BMVEC. $n=6$. Mean \pm SD. ${ }^{\mathrm{b}} P<0.05$ vs controls. ${ }^{\mathrm{e}} P<0.05$ vs TNF- $\alpha$ alone. (A) Detection of mRNA for ET-1 and $\beta$-actin in the BMVEC. (B) Relative expression of ET-1 normalized against $\beta$-actin.

Table 2. Effects of Tan IIA on TNF- $\alpha$-induced ET-1 or large ET-1 production in BMVEC. $n=6$. Mean \pm SD. ${ }^{\mathrm{b}} P<0.05 v s$ controls. ${ }^{\mathrm{e}} P<0.05 v s$ TNF- $\alpha$ alone.

\begin{tabular}{lccccc}
\hline Control & $\begin{array}{c}\text { TNF- } \alpha(5 \mu \mathrm{g} / \mathrm{mL})+ \\
\text { Tan IIA }(0 \mu \mathrm{g} / \mathrm{mL})\end{array}$ & $\begin{array}{c}\text { TNF- } \alpha(5 \mu \mathrm{g} / \mathrm{mL})+ \\
\text { Tan IIA }(5 \mu \mathrm{g} / \mathrm{mL})\end{array}$ & $\begin{array}{c}\text { TNF- } \alpha(5 \mu \mathrm{g} / \mathrm{mL})+ \\
\text { Tan IIA }(10 \mu \mathrm{g} / \mathrm{mL})\end{array}$ & $\begin{array}{c}\text { TNF- } \alpha(5 \mu \mathrm{g} / \mathrm{mL})+ \\
\text { Tan IIA }(20 \mu \mathrm{g} / \mathrm{mL})\end{array}$ \\
\hline & & & & & \\
ET-1 $(\mathrm{ng} / \mathrm{mL})$ & $0.086 \pm 0.007$ & $0.376 \pm 0.008^{\mathrm{b}}$ & $0.326 \pm 0.007^{\text {be }}$ & $0.285 \pm 0.005^{\text {be }}$ & $0.254 \pm 0.007^{\text {be }}$ \\
Large ET-1 $(\mathrm{ng} / \mathrm{mL})$ & $0.050 \pm 0.004$ & $0.260 \pm 0.004^{\mathrm{b}}$ & $0.277 \pm 0.005^{\text {be }}$ & $0.300 \pm 0.004^{\text {be }}$ & $0.321 \pm 0.007^{\text {be }}$ \\
\hline
\end{tabular}


and $1.02 \pm 0.10$, respectively; $P>0.05$ vs $1.13 \pm 0.13 ; n=6$ ).

Effects of Tan IIA on TNF- $\alpha$-induced mRNA expression of $\mathbf{E T}_{\mathbf{A}}$ or $\mathbf{E T}_{\mathbf{B}}$ in BMVEC To evaluate the effect of Tan IIA on the mRNA expression of $\mathrm{ET}_{\mathrm{A}}$ in BMVEC stimulated with TNF- $\alpha$, we explored the expression of $\mathrm{ET}_{\mathrm{A}}$ or $\mathrm{ET}_{\mathrm{B}}$ with RTPCR. As shown in Figures 4 and 5, TNF- $\alpha$ exposure resulted in a significantly increased $\mathrm{mRNA}$ expression of $\mathrm{ET}_{\mathrm{A}}(1.27 \pm$ $0.09 ; P<0.05$ vs $0.50 \pm 0.13 ; n=6)$. However, there was no appreciative effect on the $\mathrm{ET}_{\mathrm{B}}$ receptor mRNA expression $(0.33 \pm 0.05 ; P>0.05$ vs $0.34 \pm 0.04 ; n=6)$. Compared with TNF- $\alpha$ alone, Tan IIA exposure resulted in a significant decrease in

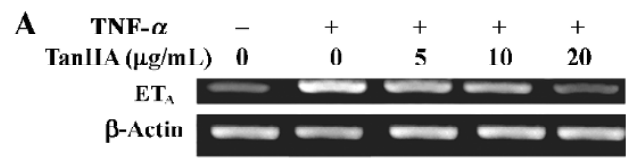

$\mathbf{B}$

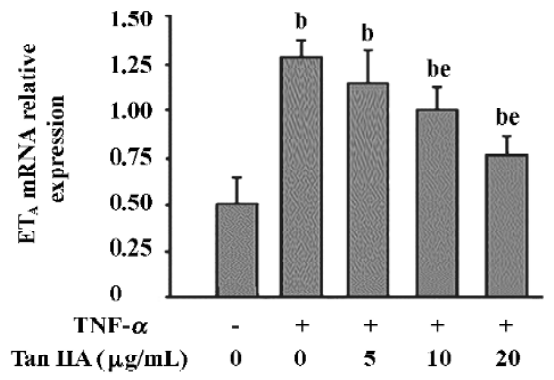

Figure 4. Effects of Tan IIA on TNF- $\alpha$-induced mRNA expression of $\mathrm{ET}_{\mathrm{A}}$ in the BMVEC. $n=6$. Mean \pm SD. ${ }^{\mathrm{b}} P<0.05 v s$ controls. ${ }^{\mathrm{e}} P<$ 0.05 vs TNF- $\alpha$ alone. (A) Detection of $m R N A$ for $\mathrm{ET}_{\mathrm{A}}$ and $\beta$-actin in the BMVEC. (B) Relative expression of $\mathrm{ET}_{\mathrm{A}}$ mRNA normalized against $\beta$-actin.

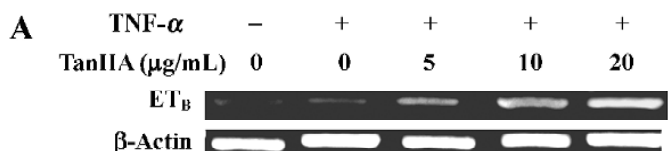

$\mathbf{B}$

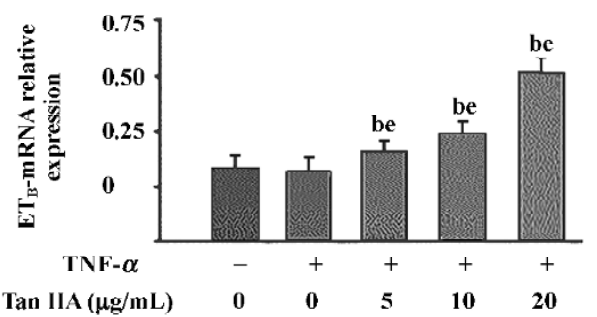

Figure 5. Effects of Tan IIA on TNF- $\alpha$-induced mRNA expression of $\mathrm{ET}_{\mathrm{B}}$ in BMVEC. $n=6$. Mean \pm SD. ${ }^{\mathrm{b}} P<0.05$ vs controls. ${ }^{\mathrm{e}} P<0.05$ vs TNF- $\alpha$ alone. (A) Detection of mRNA for $\mathrm{ET}_{\mathrm{B}}$ and $\beta$-actin in the BMVEC. (B) Relative expression of $\mathrm{ET}_{\mathrm{B}}$ mRNA normalized against $\beta$-actin. the $\mathrm{ET}_{\mathrm{A}}$ mRNA expression at concentrations of 10 and $20 \mu \mathrm{g} / \mathrm{mL}$ (1.00 \pm 0.12 and $0.75 \pm 0.09$, respectively; $P<0.05$ vs $1.27 \pm 0.09$; $n=6)$. Tan IIA $(5 \mu \mathrm{g} / \mathrm{mL})$ downregulated $\mathrm{ET}_{\mathrm{A}} \mathrm{mRNA}$, but the difference was not significant $(1.13 \pm 0.18 ; P>0.05$ vs $1.27 \pm$ $0.09 ; n=6)$. Tan IIA $(5,10$, and $20 \mu \mathrm{g} / \mathrm{mL})$ caused a significant

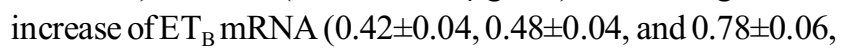
respectively; $P<0.05$ vs $0.33 \pm 0.05 ; n=6)$.

Endothelin receptor binding Receptor binding studies were conducted to characterize the effects of Tan IIA on the interaction of ET- 1 with endothelial receptor binding. The cells were incubated for $2 \mathrm{~h}$ at $37{ }^{\circ} \mathrm{C}$ with ${ }^{125} \mathrm{I}$-ET- 1 and increasing concentrations of unlabeled ET-1 in the presence or absence of TNF- $\alpha$ and Tan IIA at the indicated concentrations. As shown in Figure 6, binding for ${ }^{125}$ I-ET-1 was measured. Endothelial receptor binding was unaltered in BMVEC stimulated with TNF- $\alpha$ alone or with a combination of TNF- $\alpha$ and Tan IIA.

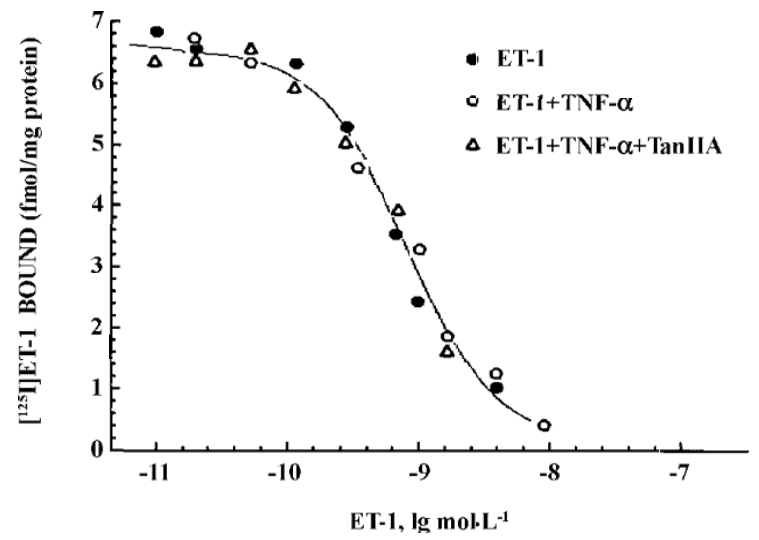

Figure 6. Endothelial receptor binding. Cells were incubated for $2 \mathrm{~h}$ in binding medium containing $1 \times 10^{-11} \mathrm{~mol} / \mathrm{L}{ }^{125} \mathrm{I}-\mathrm{ET}-1$ and increasing concentrations of unlabeled ET-1 in the presence or absence of TNF$\alpha$ and Tan IIA at 3 increasing concentrations $(5,10$, and $20 \mu \mathrm{g} / \mathrm{mL})$. Values were corrected for non-specific binding. Each point is the mean value from 2 plates of cells. One representative of 3 experiments is shown.

\section{Discussion}

Increased circulating concentrations of TNF- $\alpha$ are seen in several pathological conditions associated with vascular disease. The effect of TNF- $\alpha$ was evident in endothelial cells derived from a variety of sources. The release of ET-1 can be modulated by TNF- $\alpha^{[9-11]}$. Our findings show that TNF- $\alpha$ exposure led to increased levels of ET- 1 and increased $\mathrm{ET}_{\mathrm{A}}$ receptor mRNA. The increase in ET-1 secretion was accompanied by a corresponding increase in the ET-1 gene resulting in augmented prepro ET-1 mRNA transcription 
levels. Following TNF- $\alpha$ exposure, the ECE-1 mRNA expression was increased, which may directly result in the elevation of ET-1 levelswith a reduction of large ET-1 levels. These responses of BMVEC to TNF- $\alpha$ exposure would be expected to exert multiple biological effects in several neurological and pathological conditions. It has been shown that ET-1 is produced by BMVEC in response to TNF- $\alpha$ to mediate bloodbrain barrier (BBB) disruption ${ }^{[22]}$. Following both stroke and trauma, despite the fact that TNF- $\alpha$ has vasodilatory action achieved through the production of $\mathrm{NO}^{[23,24]}$, TNF- $\alpha$ can acutely reduces regional cerebral blood volume, followed by breakdown of the BBB and a reduction in tissue water diffusion mediated via the action of ET on its receptors ${ }^{[25]}$. TNF- $\alpha-$ stimulated vasoconstriction in cerebral vessels suggests that there are regional differences in vascular sensitivity to ET-1. The interaction between local TNF- $\alpha$ and ET-1 and the resulting regional hemodynamic actions need to be further investigated.

In pathological conditions, such as $\mathrm{SAH}$ and traumatic brain injury, stimulation of the cerebral ET system seems to play an important pathophysiological role ${ }^{[1,7,26]}$. Accordingly, interference with the actions of ET-1 may be a worthwhile therapeutic approach, and receptor antagonists have been proven effective in animal experiments. However, although preliminary clinical data has indicated the safety, there are still limited effects of the $\mathrm{ET}_{\mathrm{A}}$ or $\mathrm{ET}_{\mathrm{B}}$ receptor antagonists in treating cerebral vasospasm after $\mathrm{SAH}$ in humans. It may provoke a drastic elevation of intracerebral ET-1 concentrations as the result of antagonists competing for ET binding sites $^{[27,28]}$. Therefore, reducing the synthesis and release of ET-1 from endothelial or parenchymal cells mayprove a worthwhile alternative or adjunctive therapeutic option.

The results of our study, show for the first time that Tan IIA may be involved in the processing of large ET-1 to ET-1. This study demonstrates the inhibitory action of Tan IIA in elevating ET-1 levels in cell culture media under stimulated conditions. Theoretically, the decrease in ET-1 caused by Tan IIA may be due to a decrease in production or an increase in cellular binding/uptake or in degradation. However, an increase in ET-1 mRNA was not detectable by RT-PCR under these conditions. Although Tan IIA-induced decreases in ET-1 were not accompanied by a rise in protein synthesis, our data showed a considerable increase in the precursor peptide of large ET-1 as well as a decrease in ET-1. The effects of Tan IIA on ET receptor expression may lead to changes in ET-1 levels and its biological effects. In our study, Tan IIA exposure led to decreased $\mathrm{ET}_{\mathrm{A}}$ receptor $\mathrm{mRNA}$ and increased $\mathrm{ET}_{\mathrm{B}}$ receptor mRNA. These responses of BMVEC to Tan IIA exposure would be expected to lead to vasodilatation of cerebral vasculature in vivo. Moreover, an upregula-tion of $\mathrm{ET}_{\mathrm{B}}$ receptors may lead to an increase in ET-1 binding which will decrease ET-1 levels ${ }^{[29]}$. To determine whether the decreased ET-1 level in BMVEC was due to enhanced endothelial receptor binding, receptor binding studies were conducted. We found that endothelial receptor binding was unaltered in BMVEC stimulated with TNF- $\alpha$ alone or in the combination of TNF- $\alpha$ and Tan IIA. Taken together, the effect of Tan IIA may be partially attributable to a decrease in ET-1 synthesis. The synthesis of ET-1 starts with the generation of a prepropeptide processed by enzymes of the constitutive secretory pathway to the immediate precursor, large ET-1.

Large ET-1 by itself does not bind to any of the known ET receptors; it is cleaved enzymatically, resulting in the release of the so-called C-terminal fragment and mature ET-1. The latter exclusively mediates the biological effects. Enzymatic processing of large ET-1 occurs at an unusual scission site and is the critical step in ET- 1 formation. To date, 2 different specificECE(ECE-1 andECE-2) have been identified. In most tissues, the expression of the ECE-1 subtype seems to exceed that of ECE- ${ }^{[30]}$. Accordingly, large ET-1 released from endothelial and parenchymal cells seems to be processed predominantly by ECE-1 activity. Therefore, our study lends evidence to the existence of Tan IIA with influence upon ECE-1 activity. The decreased level of ECE-1 assessed semiquantitatively in the present study confirmed our hypothesis; it is possible that Tan IIA inhibits the cleavage of large ET into ET-1, which would explain why Tan IIA decreases ET-1 concentration while large ET concentrations show a parallel increase.

The inhibition of ECE-1 by Tan IIA shown in the present study represents a novel finding. We demonstrate for the first time that Tan IIA decreases TNF- $\alpha$-induced ET- 1 expression in BMVEC through the suppression of ECE-1 synthesis. These results may at least partially explain the cerebral vessel benefits of SM. Although suggestive, further studies need to be carried out to elucidate the extent to which ECE-1 is affected by Tan IIA in vitro and in vivo, and the modulatory mechanism needs to be elucidated.

\section{References}

1 Andresen J, Shafi NI, Bryan RM. Endothelial influences on cerebrovascular tone. J Appl Physiol 2006; 100: 318-27.

2 Yakubu MA, Shibata M, Leffler CW. Hematoma-induced enhanced cerebral vasoconstrictions to leukotriene $\mathrm{C} 4$ and endothelin-1 in piglets: role of prostanoids. Pediatric Re 1995; 38: 119-23

3 Yakubu MA, Leffler CW. Role of endothelin-1 in cerebral hematoma-induced modification of cerebral vascular reactivity in 
piglets. Brain Res 1996; 734: 149-56.

4 Yakubu MA, Leffler CW. L-type voltage-dependent $\mathrm{Ca}^{2+}$ channels in cerebral microvascular endothelial cells and ET-1 biosynthesis. Am J Physiol Cell Physiol 2002; 283: C1687-95.

5 Clozel M, Gray GA, Breu V, Loffler BM, Osterwalder R. The endothelin $\mathrm{ET}_{\mathrm{B}}$ receptor mediates both vasodilation and vasoconstriction in vivo. Biochem Biophys Res Commun 1995; 186: 867-73.

6 Naidoo V, Naidoo S, Mahabeer R, Raidoo DM. Cellular distribution of the endothelin system in the human brain. J Chem Neuroanat 2004; 27: 87-98.

7 Juvela S. Plasma endothelin and big endothelin concentrations and serum endothelin-converting enzyme activity following aneurysmal subarachnoid hemorrhage. J Neurosurg 2002; 97:1287-93.

8 Kwan AL, Lin CL, Chang CZ, Wu SC, Howng SL, Jeng AY. Attenuation of SAH-induced cerebral vasospasm by a selective ECE inhibitor. Neuroreport 2002; 13: 197-9.

9 Marsden PA, Brenner BM. Transcriptional regulation of the endothelin-1 gene by TNF-alpha. J Physiol Cell Physiol 1992; 262: 854-61.

10 Zhao RZ, Chen X, Yao Q, Chen C. TNF-alpha induces interleukin8 and endothelin-1 expression in human endothelial cells with different redox pathways. Biochem Biophys Res Commun 2005; 327: 985-92.

11 Molet S, Furukawa K, Maghazechi A, Hamid Q, Giaid A. Chemokine- and cytokine-induced expression of endothelin-1 and endothelin-converting enzyme-1 in endothelial cells. J Allergy Clin Immunol 2000; 105: 333-8.

12 Ji XY, Tan BKH, Zhu YZ. Salvia miltiorrhiza and ischemic diseases. Acta Pharmacol Sin 2000; 21: 1089-94.

13 Chan K, Chui SH, Wong DY, Ha WY, Chan CL, Wong RN. Protective effects of Danshensu from the aqueous extract of Salvia miltiorrhiza (Danshen) against homocysteine-induced endothelial dysfunction. Life Sci 2004; 75: 3157-71.

14 Xu M, Wang YP, Luo WB, Xuan LJ. Salvianolate inhibits proliferation and endothelin release in cultured rat mesangial cells. Acta Pharmacol Sin 2001; 22: 629-33.

15 Xia ZY, Gu JZ, Ansley DM, Xia F, Yu JF. Antioxidant therapy with Salvia miltiorrhiza decreases plasma endothelin-1 and thromboxane $\mathrm{B}_{2}$ after cardiopulmonary bypass in patients with congenital heart disease. J Thorac Cardiovasc Surg 2003; 126: 140410.

16 Jang SI, Jeong SI, Kim KJ, Kim HJ, Yu HH, Park R, et al. Tanshinone IIA from Salvia miltiorrhiza inhibits expression of inducible nitric oxide synthase and production of TNF- $\alpha$, IL- $1 \beta$ and IL-6 in activated RAW 264.7 cells. Planta Med 2003; 69: 1057-9

$17 \mathrm{Kim} \mathrm{HH,} \mathrm{Kim} \mathrm{JH,} \mathrm{Kwak} \mathrm{HB,} \mathrm{Huang} \mathrm{H,} \mathrm{Han} \mathrm{SH,} \mathrm{Ha} \mathrm{H,} \mathrm{et} \mathrm{al.}$ Inhibition of osteoclast differentiation and bone resorption by tanshinone IIA isolated from Salvia miltiorrhiza. Bunge Biochem Pharmacol 2004; 67: 1647-56.
18 Abbott NJ, Hughes CC, Revest PA, Greenwood J. Development and characterisation of a rat brain capillary endothelial culture: towards an in vitro blood-brain barrier. J Cell Sci 1992; 103: 2337.

19 Sakurai T, Yanagisawa M, Takuwa Y, Miyazaki H, Coto K, Masaki T. Cloning of a cDNA encoding a non-isopeptide-selective subtype of the endothelia receptor. Nature 1990; 348: 732-5.

20 Sakurai T, Yanagisawa M, Inoue A, Ryan US, Kimura S, Mitsui Y, et al. cDNA cloning, sequence analysis and tissue distribution of rat preproendothelin-1 mRNA. Biochem Biophys Res Commun 1991; 175: 44-7.

21 Shimada K, Takahashi M, Tanzawa K. Cloning and functional expression of endothelial-converting enzyme from rat BMVEC. J Biol Chem 1994; 269: 18 275-8.

22 Didier N, Romero IA, Creminon C, Wijkhuisen A, Grassi J, Mabondzo A. Secretion of interleukin- $1 \beta$ by astrocytes mediates endothelin-1 and tumour necrosis factor- $\alpha$ effects on human brain microvascular endothelial cell permeability. J Neurochem 2003; 86: 246-54.

23 Macnaul KL, Hutchinson NI. Differential expression of iNOS and cNOS mRNA in human vascular smooth muscle cells and endothelial cells under normal and inflammatory conditions. Biochem Biophys Res Commun 1993; 196: 1330-4.

24 Hollenberg SM, Cunnion RE, Parrillo JE. The effect of tumor necrosis factor on vascular smooth muscle. In vitro studies using rat aortic rings. Chest 1991; 100: 1133-7.

25 Sibson NR, Blamire AM, Perry VH, Gauldie J, Styles P, Anthony DC. TNF-alpha reduces cerebral blood volume and disrupts tissue homeostasis via an endothelin- and NFR2-dependent pathway. Brain 2002; 125: 2446-59.

26 Armstead WM. Endothelin-induced cyclooxygenase-dependent superoxide generation contributes to $\mathrm{K}^{+}$channel functional impairment after brain injury. J Neurotrauma 2001; 18: 1039-48.

27 Plumpton C, Ferro CJ, Haynes WG, Webb DJ, Davenport AP. The increase in human plasma immunoreactive endothelin but not big endothelin-1 or its C-terminal fragment induced by systemic administration of the endothelin antagonist TAK-044. Br J Pharmacol 1996; 119: 311-4.

28 Chuquet J, Benchenane K, Toutain J, MacKenzie ET, Roussel S, Touzani O. Selective blockade of endothelin-B receptors exacerbates ischemic brain damage in the rat. Stroke 2002; 33: 301924.

29 Pollock DM, Allcock GH, Krishnan A, Dayton BD, Pollock JS. Upregulation of endothelin B receptors in kidneys of DOCA-salt hypertensive rats. Am J Physiol Renal Physiol 2000; 278: 27986.

30 Parnot C, Le Moullec JM, Cousin MA, Guedin D, Corvol P, Pinet F. A live-cell assay for studying extracellular and intracellular endothelin-converting enzyme activity. Hypertension 1997; 31: $837-44$. 